\title{
Jiang Finally Steps Down: A Note on Military Personnel Changes and the CCP's Governing Capacity
}

KJELD ERIK BRØDSGAARD

During the period 16-19 September 2004, the 16th Central Committee of the Chinese Communist Party (CCP) held its 4th Plenary Session, which was attended by 198 full members and 158 alternate members. At this meeting it was decided that Jiang Zemin, 78, would step down as Chairman of the Central Military Commission (CMC) to be followed by President and General Secretary Hu Jintao, 61. By this change of guard, the transition from the so-called third generation to the fourth generation of Chinese leaders was completed.

During the weeks leading up to this important meeting of the Central Committee there was intense speculation in Western news media that a power struggle was waging in the upper echelons of the CCP (Forney 2004; Kahn 2004). Apparently, Jiang Zemin was advancing all kinds of preconditions for stepping down, effectively making it impossible to reach a resolution of the succession issue. It was also rumoured that if Jiang were to step down, he would make sure that his right-hand man and close ally Vice-President Zeng Qinghong would be appointed vicechairman of the CMC, so that Hu Jintao's power would effectively be counterweighted. However, Jiang stepped down in an orderly fashion and Zeng Qinghong was not appointed vice-chairman. Instead a military man, Xu Caihou, took up the post. Furthermore, Admiral Zhang Dingfa and Generals Chen Bingde, Qiao Qingchen and Jing Zhiyuan were promoted to the $\mathrm{CMC}$, so that the top military organ now has 11 members compared to 8 under Jiang. In sum, new leaders were once again elected without drama and apparent in-fighting. Thus the impression that Chinese politics has entered a stable new phase of predictable institutionalization has been further strengthened (Brødsgaard 2003).

There are several reasons why Jiang Zemin decided to step down. $\mathrm{Hu}$ Jintao has by now clearly consolidated his power in the Party. There has been much speculation that his manoeuvrability in the Politburo standing committee was restricted by the presence of a majority of Jiang 
supporters in this top policy-making organ. However, all the indications are that $\mathrm{Hu}$ in fact commands a majority in the Politburo and is not encountering any strong opposition. He may now feel he is ready to assume the leadership of the army and, faced with such a situation, Jiang decided to bow to the new top man. Secondly, Jiang did not have much to gain by staying on. Many Chinese believe that he has already overstayed his role and that if he were to cling to power, this would effectively damage Jiang's legacy. Thirdly, and perhaps more importantly, during the recent commemorations of the 100th anniversary of the birth of Deng Xiaoping, CCP leaders praised Deng for having given up his party and military positions before he died in 1997 (China aktuell 2004). Hu said at the meeting that Deng, by abolishing life-long tenure for officials and leaders, had set a personal example. In fact, Deng stepped down as member of the Politburo in 1987 and retired from the chairmanship of the CMC two years later (November 1989). Even if he had wanted to, it would had been extremely difficult for Jiang Zemin to ignore Deng's example. Therefore since Jiang retired from the Politburo in September 2002, he was bound to fully step down two years later. Deng's legacy still looms large in China and to ignore it would not be possible.

This is not to say that Jiang will not continue to wield influence in both the Party and the military. He clearly will do so, although he is now fully retired. He was party leader for 13 years during a crucial period of the Chinese reform process and this alone gives him considerable influence. As to the military, Jiang has appointed 79 full generals during his tenure as chairman of the Central Military Commission (CMC) and many of these generals owe him their thanks if not their loyalty. However, Jiang did not manage to have his close ally, Vice-President Zeng Qinghong appointed to the $\mathrm{CMC}$, which implies either that he stepped down without any preconditions or that Hu Jintao was strong enough to block the appointment in order not to have his power within the CMC curbed.

The new CMC consists of the following members: General Secretary $\mathrm{Hu}$ Jintao is chairman, while Minister of Defence Cao Guangchuan, former Executive Chief of Staff of PLA Guo Boxiong, and Director of the Political Department of the PLA Xu Caihou serve as the three vicechairmen. Chief of General Staff Liang Guanglie, Director of the General Armament Department Li Jinai and Director of the General Logistics Department Liao Xilong have all served as ordinary members since 2002. They have now been joined by the commanders of the Navy, Air Force, and PLA Second Artillery, namely Admiral Zhang Dingfa and 
Generals Qiao Qingchen and Jing Zhiyuan. Finally the commander of the Jinan Military Region, Chen Bingde, has been elevated to the Central Military Commission (see Table 1).

TABLE 1: Composition of the Central Military Commission (CMC) Elected at the $4^{\text {th }}$ Plenary Session of the $16^{\text {th }}$ CC of the CCP

\begin{tabular}{|l|l|}
\hline Name & Position \\
\hline Cao Guntao & $\begin{array}{l}\text { Chairman of the CMC, General Secretary of the CCP, Presi- } \\
\text { dent of the PRC }\end{array}$ \\
\hline Guo Boxiong & $\begin{array}{l}\text { Vice-Chairman of the CMC, Defence Minister, Member of } \\
\text { Politburo }\end{array}$ \\
\hline Xu Caihou & Vice-Chairman of CMC, Member of Politburo \\
\hline Liang Guanglie & $\begin{array}{l}\text { Vice-Chairman of the CMS, Director of the General Political } \\
\text { Dept. of the PLA }\end{array}$ \\
\hline Li Jinai & $\begin{array}{l}\text { Member of the CMC, Chief of General Staff } \\
\text { partment }\end{array}$ \\
\hline Liao Xilong & $\begin{array}{l}\text { Member of the CMC, Director of the General Logistics De- } \\
\text { partment }\end{array}$ \\
\hline Chen Bingde & Member of the CMC, Commander of Jinan Military Region \\
\hline Qiao Qingchen & Member of the CMC, Commander of PLA Air Force \\
\hline Zhang Dingfa & Member of the CMC, Commander of PLA Navy \\
\hline Jiang Zhiyuan & Member of the CMC, Commander of PLA Second Artillery \\
\hline
\end{tabular}

Sources: China aktuell (August 2004); Beijing Review.

The new line-up of the CMC includes only one civilian, namely $\mathrm{Hu}$ Jintao, and seems to reflect a trend of combat readiness in Zhongnanhai, the central power centre in Beijing. Jing Zhiyuan is as Commander of the PLA Second Artillery in charge of China's missile forces. His appointment brings the technologically advanced part of the PLA into the CMC. Chen Bingde is former head of the Nanjing Military Region, a crucial region in Beijing's military strategy versus Taiwan, and his appointment to the CMC strengthens the perception of urgency in dealing with the Taiwan question. In short, the new line-up by integrating navy, air, army and the missile forces plus the important Jinan and Beijing Military Regions, will facilitate the preparation and consolidation of the military option vis-à-vis the Taiwan issue, in the eventuality that crossstraits relations deteriorate beyond a diplomatic solution.

This is not to say that there will necessarily be a change in mainland China's Taiwan policy. There has been speculation that $\mathrm{Hu}$ will be more 
flexible and accommodating in his stance on the Taiwan issue. However, it is difficult to substantiate any disagreements between $\mathrm{Hu}$ and Jiang on this issue. In the event that policies should shift, this is likely to be the outcome of changing circumstances rather than differences in opinion among the various factions of the military and political leadership.

\section{Jiang's Legacy}

Jiang Zemin led China during a particularly difficult period. When he assumed power in June 1989, China was in the middle of a deep crisis. The crackdown on the students on 4 June had created deep internal division, aggravated by the sanctions that the US and the EU quickly introduced. Many scholars predicted that the days of the CCP were numbered and that there would be a change of regime. Such expectations were further strengthened as a consequence of the collapse of communism in the Soviet Union and in Eastern Europe during 1989-91. Jiang had been selected by Deng and a gerontocratic group of the so-called 'eight immortals' as new CCP leader in the summer of 1989 on the premise that he would continue to push for economic reform. When he hesitated to live up to his promise, Deng reportedly was ready to topple him, just as he had done to $\mathrm{Hu}$ Yaobang and Zhao Ziyang when they did not live up to his expectations. However, Jiang was able to adjust and from 1992 reform and an 'opening-up' policy again took centre-stage in China. That he was able to extricate himself successfully from the emerging leadership crisis in 1992 shows his great pragmatism and ability to manoeuvre politically. During the remaining part of the 1990s, Jiang continued to lead China down the path of rapid economic growth. This Wirtschaftwunder combined with a foreign policy of 'big power diplomacy' fundamentally strengthened China's international standing.

By the turn of the century, China enjoyed a stronger position on the world stage than it had ever held since 1949. It had restarted economic growth in the wake of the Tiananmen débâcle, dramatically expanded foreign trade, and boosted the absorption of foreign direct investment. It had restored relations with those same Western countries that had imposed sanctions in 1989. China now holds regular summits with the US, is invited to meetings in the G7 group and has been admitted to the WTO. It has won back Hong Kong and Macau and has been selected to host the 2008 Olympics, against fierce international competition (Nathan 2003). In short, China's prestige, standing and influence have by any measure increased immensely during Jiang Zemin's rule.

In 2000, as Jiang was approaching the end of his tenure as China's 
supreme leader, he advanced the theory of 'the Three Represents' (sange daibiao). This theory paved the way for the ideological emancipation of the private entrepreneurs and made it possible to invite 'these advanced elements' of the new economy to join the CCP (Holbig 2002). Sange daibiao has been included in the constitution of the PRC and will be regarded as Jiang's theoretical legacy.

However, Jiang Zemin is not Deng Xiaoping and does not enjoy the same status as Deng, who never needed to hold the formal top position in the party or state apparatus in order to wield supreme power. Therefore he will not enjoy the same influence in his retirement as Deng did. Furthermore, there does not seem to be a Politburo decision in place, as there was in 1987, to give the retired leader the right to intervene or to be heard in major decisions.

Consequently the new leader $\mathrm{Hu}$ Jintao will have a freer hand in leading China than Jiang had when he took over. The basic line of incremental reform will probably remain unchanged, but already there are indications that the Shanghai and the Eastern provinces will receive relatively less attention. Hu Jintao and Premier Wen Jiabao have already indicated that they are leaning toward more redistributionist policies in order to reduce the immense inequalities that exist between Eastern and Western provinces and between rural and urban China. Such a change in the central leadership's attention will shift the focus away from the Shanghai area to the benefit of Northern China.

\section{The CCP's Capacity to Govern}

Apart from announcing the formal retirement of Jiang Zemin, one of the most important decisions taken at the recent 4th Plenary Session of the Central Committee of the CCP was about strengthening the Party's governing capacity (zhizheng nengli).

The Hu Jintao leadership appears to be convinced that China's future economic development and reform depend on creating a strong government that is competent and professional. The SARS crisis in the spring and early summer of 2003 demonstrated a lack of capacity on the part of the government to handle complex new situations. The ensuing crisis challenged the authority of the new leadership and damaged China's international standing. The CCP leadership under $\mathrm{Hu}$ will do its utmost to make sure that a similar situation of confusion in the governing bodies does not happen again. Therefore there will be a focus on creating a more efficient and responsive government. Since the government and 
its civil servants are controlled by the CCP, it is ultimately a question of strengthening the Party's capacity to govern effectively.

Over the past couple of years the CCP has published six major documents to reform and regularize cadre supervision and discipline and to routinize promotions of civil servants. These documents include the 2002 Regulations on Selection and Appointment of Party and Government Leading Cadres (Regulations 2002), the recently promulgated Regulations of the CPC on Internal Supervision (Trial Implementation) and the Regulations of the CPC on Disciplinary Penalties. Moreover, there has been a sustained effort to professionalize the work of Party and state cadres. Part of these efforts has been to introduce educational and age criteria for cadre promotion (Brødsgaard 2004).

However, a recent survey conducted by the Central Party School among cadres at county level and above indicates that many leading cadres lack the ability to lead and govern. According to the survey, 58 percent demonstrated a lack of ability to 'make a scientific judgment of a situation', while more than one-third either 'had difficulty tackling a complicated situation' or 'totally lost their heads' in such a situation. The widespread public panic during the early stages of the SARS outbreak in the spring of 2003 was an example of the lack of government capability to handle an emergency situation (Ni 2004).

The 'Decision of the Central Committee of the Communist Party of China on Strengthening the Party's Governing Capacity' (Decision 2004), adopted by the 4th Plenary Session on 16 September 2004, shows that the CCP leadership is firmly committed to strengthening governance and leadership. This will be done by focusing on Party renewal and Party adaptation to the new economic and social imperatives in China today. The $\mathrm{Hu}$ Jintao leadership understands political reform as a reform of the political system, not as basic political and social changes. Political reform in Hu's China is not about the introduction of a Western form of democracy, because this would essentially mean sharing power with, or eventually ceding power to, other groups of political contenders. The new leadership is not prepared to accept such a scenario.

\section{Conclusion}

The recent 4th Plenary Session shows that the institutionalization of Chinese politics is continuing in a routine and stable manner. The transition to a new leadership has for the first time been completed in a peaceful and orderly fashion in conformity with agreed norms and rules. The new leadership is eager to carry out this process of institutionalization 
and normativization at all levels of the Chinese bureaucracy. In fact, they believe that the success of this process will ultimately decide whether the present political system - with its inherent control and domination by the CCP - will continue to have a future.

Kjeld Erik Brodsgaard is Professor and Director of the Asia Research Centre, Copenhagen Business School.

\section{REFERENCES}

Beijing Review 2004. 47 (39), 30 September.

Brødsgaard, Kjeld Erik 2003. 'The 10th National People's Congress in China: A Note on Personnel Changes and Economic Achievements'. The Copenhagen Journal of Asian Studies 17: 78-86.

- 2004. 'The Role of the Communist Party in China's Leadership Transition'. Daxiyangguo: Revista Portuguesa de Estudos Asiáticos 5 (Spring): 105-30.

China aktuell 2004. August edition.

'Dang zhengfu lingdao ganbu xuanba renyong gongzuo tiaoli' [Regulations on Selection and Appointment of Party and Government Leading Cadres] 2002. Renmin ribao, 23 July.

Forney, Matthew 2004. 'First or Equals? China's President Hu Wants to Consolidate his Power, but his Predecessor Jiang Zemin Has Not Yet Faded Away'. Time Magazine Asia 164 (12).

Holbig, Heike 2002. 'The Party and Private Entrepreneurs in the PRC'. The Copenhagen Journal of Asian Studies 16: 30-56.

Kahn, Joseph 2004. 'China's Two Top Leaders Square Off in Contest to Run Policy'. New York Times, 2 September.

Nathan, Andrew 2003. 'Authoritarian Resilience'. Journal of Democracy 14 (1): 6-17.

Ni Yanshuo 2004. 'Keeping up with Change'. Beijing Review 47 (39): 24-25.

'Zhonggong zhonyang guanyu jiaqiang dang de zhineng nengli jianshe de jueding' [Decision of the Central Committee of the Communist Party of China on Strengthening the Party's Governing Capacity] 26 September 2004. Beijing: Xinhua wang. 